Intecoms: Journal of Information Technology and Computer Science

Volume 1 Nomor 1, Juni 2018

e-ISSN : 2614-1574

p-ISSN : 2621-3249

DOI : https://doi.org/10.31539/intecoms.v1i1.142

\title{
PRESENSI ONLINE MENGGUNAKAN RFID PADA KARTU MAHASISWA
}

\section{ONLINE PRESENCE USING RFID ON STUDENT CARDS}

\author{
Salhazan Nasution \\ Program Studi Teknik Informatika, Universitas Riau \\ salhazan@lecturer.unri.ac.id
}

\begin{abstract}
Information technology is no longer a complement, but a necessity in the academic world especially University. The presence of students in lectures is one important component in the learning process. The more students attend the class, the more students understand the lesson. In addition, the number of student attendance can also be a consideration for the lecturer in evaluating and taking action against the student. The current student attendance record is mostly still done manually by signing on a paper. The increasing number of students from year to year in University requires a system that can manage a large number of students' data and the speed in obtaining access to information requires the university to build a system that can assist in the administration process in University. Online Presence System is a solution to overcome this, with this system then the recording of student presences can be done by scanning the RFID contained in the student card, no longer done manually using paper (paperless). This will assist lecturers and administrative staff in managing the recapitulation of student attendance and can be a consideration for lecturers in evaluating and taking action against the students concerned. In addition, this system will become a computerized data warehouse that stores the archives of student data in large numbers.
\end{abstract}

Keyword: Online Presence System, RFID, Presentation, Attendance, Lecture

\begin{abstract}
ABSTRAK
Teknologi informasi bukan lagi sebagai pelengkap, tapi merupakan kebutuhan dalam dunia akademis terutama perguruan tinggi. Kehadiran mahasiswa dalam perkuliahan merupakan salah satu komponen yang penting dalam proses belajar mengajar. Dengan semakin sering mahasiswa masuk kelas, maka semakin sering pula intensitas mahasiswa dalam menerima pelajaran yang akan berpengaruh terhadap tingkat kepahaman mahasiswa terhadap matakuliah yang ditempuhnya. Selain itu, tingkat presentasi kehadiran mahasiswa juga dapat menjadi bahan pertimbangan bagi dosen dalam mengevaluasi dan mengambil tindakan terhadap mahasiswa tersebut. Proses pencatatan kehadiran mahasiswa saat ini kebanyakan masih dilakukan secara manual dengan membubuhkan tanda tangan pada kertas. Dengan banyaknya jumlah mahasiswa dari tahun ke tahun pada setiap perguruan tinggi, kebutuhan akan suatu sistem yang dapat mengelola data-data mahasiswa serta kecepatan akses dalam memperoleh informasi menuntut pihak Universitas untuk membangun suatu sistem yang dapat membantu proses administrasi perkuliahan. Sistem Presensi Online merupakan suatu solusi untuk mengatasi hal tersebut, dengan sistem ini maka presensi mahasiswa dapat dilakukan dengan melakukan scan terhadap RFID yang terdapat pada kartu mahasiswa, tidak lagi dilakukan secara manual menggunakan kertas (paperless). Hal ini akan membantu dosen dan pihak administrasi Universitas dalam mengelola rekapitulasi kehadiran mahasiswa serta dapat menjadi bahan pertimbangan bagi dosen dalam mengevaluasi dan mengambil tindakan terhadap mahasiswa yang bersangkutan. Selain itu, sistem ini akan menjadi gudang data terkomputerisasi yang menyimpan arsip data-data mahasiswa dalam jumlah besar.
\end{abstract}

Kata Kunci : Sistem Presensi Online, RFID,Presensi, Absensi, Kuliah 


\section{PENDAHULUAN}

Kehadiran mahasiswa dalam perkuliahan merupakan salah satu komponen yang penting dalam proses belajar mengajar. Dengan semakin sering mahasiswa masuk kelas, maka semakin sering pula intensitas mahasiswa dalam menerima pelajaran yang akan berpengaruh terhadap tingkat kepahaman mahasiswa terhadap matakuliah yang ditempuhnya. Selain itu, tingkat presentasi kehadiran mahasiswa juga dapat menjadi bahan pertimbangan bagi dosen dalam mengevaluasi dan mengambil tindakan terhadap mahasiswa tersebut.

Seiring perkembangan teknologi, dunia akademis tidak bisa dilepaskan dari teknologi informasi. Saat ini teknologi informasi telah mencakup ke seluruh aspek, baik itu pemerintahan, industri, kesehatan, termasuk dunia akademis. Teknologi informasi bukan lagi sebagai pelengkap, tapi merupakan kebutuhan dalam dunia akademis terutama perguruan tinggi. Dengan banyaknya jumlah mahasiswa dari tahun ke tahun pada setiap perguruan tinggi, kebutuhan akan suatu sistem yang dapat mengelola data-data mahasiswa serta kecepatan akses dalam memperoleh informasi menuntut pihak Universitas untuk membangun suatu sistem yang dapat membantu proses administrasi mahasiswa tersebut.

Sistem Presensi Online merupakan suatu solusi untuk mengatasi hal tersebut. Dengan sistem ini maka mahasiswa dapat melakukan presensi langsung secara terkomputerisasi tanpa harus melakukan secara manual menggunakan kertas (paperless). Hal ini juga akan membantu dosen dan pihak administrasi Universitas dalam mengelola rekapitulasi kehadiran mahasiswa.
PHP (PHP: Hypertext

Prepocessor) pertama kali dibuat oleh Rasmus Lerdorf pada tahun 1995. Pada waktu itu PHP masih bernama FI (Form Interpreted), yang wujudnya berupa sekumpulan script yang digunakan untuk mengolah data form dari web. Selanjutnya Rasmus merilis kode sumber tersebut untuk umum dan menamakannya PHP/FI, kependekan dari Hypertext Preprocessing/Form Interpreter. Dengan perilisan kode sumber ini menjadi open source, maka banyak programmer yang tertarik untuk ikut mengembangkan PHP. Pada November 1997, dirilis PHP/FI 2.0. Pada rilis ini interpreter PHP sudah diimplementasikan dalam program $\mathrm{C}$. Dalam rilis ini disertakan juga modulmodul ekstensi yang meningkatkan kemampuan PHP/FI secara signifikan (Zend Technologies, 2015).

Pada tahun 1997, Zeev Suraski dan Andi Gutmans mulai bekerja menulis ulang interpreter dari PHP (Zend Technologies, 2015). Pekerjaan ini membantu dalam mendefinisikan ulang PHP sebagai bahasa pemrograman yang penuh dengan fitur. Zeev Suraski dan Andi Gutmans kemudian mendirikan perusahaan yang bernama Zend, perusahaan tersebut menulis ulang interpreter PHP menjadi lebih bersih, lebih baik, dan lebih cepat. Kemudian pada Juni 1998, perusahaan tersebut merilis interpreter baru untuk PHP dan meresmikan rilis tersebut sebagai PHP 3.0.

Pada pertengahan tahun 1999, Zend merilis interpreter PHP baru dan rilis tersebut dikenal dengan PHP 4.0. Kontribusi Zend berlanjut pada PHP 4.0 yang memperkenalkan Zend Engine (Zend Technologies, 2015), sebuah mesin eksekusi yang telah dioptimalkan. Peningkatan ini memperbolehkan modul-modul seperti debuggers, performance boosters dan 
custom loaders untuk secara dinamis memperluas PHP untuk fungsionalitas yang lebih luas. Zend Engine juga menyediakan pengaturan memori dan sumber daya serta layanan standar PHP lainnya. PHP 4.0 adalah versi PHP yang paling banyak dipakai pada awal abad ke-21. Versi ini banyak dipakai disebabkan kemampuannya untuk membangun aplikasi web kompleks tetapi tetap memiliki kecepatan dan stabilitas yang tinggi.

Pada Juni 2004, Zend merilis PHP 5.0. Dalam versi ini, inti dari interpreter PHP mengalami perubahan besar. Zend melanjutkan kontribusinya pada PHP dengan memperkenalkan Zend Engine 2. Kemunculan pertama Zend Engine 2 adalah pada PHP 5.0 dan telah ditambahkan model objek yang kuat dan ekstensibel serta peningkatan performa yang lebih baik lagi. Versi ini juga memasukkan model pemrograman berorientasi objek ke dalam PHP untuk menjawab perkembangan bahasa pemrograman ke arah paradigma berorientasi objek.

Oracle adalah basis data relasional yang terdiri dari kumpulan data dalam suatu sistem manajemen basis data Relational Database Management System (RDBMS). Perusahaan perangkat lunak Oracle memasarkan jenis basis data ini untuk bermacammacam aplikasi yang bisa berjalan pada banyak jenis dan merk perangkat keras komputer (platform). Basis data Oracle ini pertama kali dikembangkan oleh Larry Ellison, Bob Miner dan Ed Oates lewat perusahaan konsultasinya bernama Software Development Laboratories (SDL) pada tahun 1977. Pada tahun 1983, perusahaan ini berubah nama menjadi Oracle Corporation sampai sekarang (Oracle Technology, 2017).
Oracle menggunakan SQL (Structured query language) sebagai bahasa perantara antara user dan database. Kemudian Oracle Corp mengembangkan sebuah bahasa prosedural yang mereka sebut sebagai PL/SQL. Dengan menggunakan kedua bahasa ini, seorang user dapat mengoptimalkan penggunaan database Oracle. Oracle mendukung data yang sangat besar, menurut dokumentasi Oracle dapat menampung sampai 512 petabytes $(1$ petabytes $=1.000 .000$ gigabytes) atau sekitar 512.000 .000 gigabytes (Tarigan, 2003).

Keunggulan Oracle dibanding dengan yang lain antara lain (Computing Channel, 2010) :

Client/server environment. Oracle berjalan di jaringan komputer. Oracle memisahkan proses antara database server dan aplikasi client. Server yang terinstall Oracle bertanggung jawab menangani proses database, sementara client/workstation yang menjalankan aplikasi hanya berkonsentrasi menampilkan data. Struktur ini akan mengurangi kemacetan jaringan.

Ukuran database yang besar dan pengaturan space. Oracle mendukung ukuran database yang sangat besar hingga jumlahnya terabyte. Oracle juga mendukung pengaturan penggunaan space pada harddisk, sehingga ruangan hardisk termanfaatkan secara efisien.

Multiuser. Oracle mendukung pelayanan banyak user, yang terkoneksi pada waktu yang sama, dan mengakses data yang sama. Dengan fasilitas ini, Oracle mampu menghindari konflik data secara baik.

Connectibility. Oracle dapat menggunakan berbagai sistem operasi dalam suatu jaringan untuk mengakses data.

High Transaction Processing Performance. Oracle dapat mengatur sistem agar pemrosesan data dapat 
berjalan dengan cepat walaupun jumlah transaksi sangat banyak pada suatu waktu.

Availability. Oracle dapat menjalankan database secara terus menerus, 24 jam sehari. Pemisahan sistem komputer dan proses backup dapat dilakukan secara online, tanpa harus mematikan database.

Manajemen Keamanan yang baik. Oracle menghindari akses database dari pihak-pihak yang tidak diinginkan. Oracle memiliki fitur yang baik untuk membatasi dan memonitor akses data.

Database Enforced Integrity. Oracle mempunyai kontrol untuk mengendalikan data mana saja yang dapat diterima database. Tidak perlu membuat kode dibanyak aplikasi, cukup di satu database Oracle.

Portability. Oracle dapat berjalan diberbagai sistem operasi, baik Linux, Windows, Unix, dan masih banyak lagi. Aplikasi yang menggunakan data Oracle dapat dengan mudah mengakses data Oracle yang berjalan di sistem apapun.

Distributed System. Oracle dapat memisahkan databasenya dalam komputer-komputer yang secara fisik terpisah, namun secara logis terlihat seperti satu database.

Replicant Environment. Oracle mampu menduplikasi database object dalam lokasi server yang berbeda-beda. Hal ini sangat membantu jika salah satu server rusak, server lain dapat langsung menggantikan fungsinya.

Dalam hal kapasitas penyimpanan data, Oracle dapat menyimpan data sehingga 512 petabytes, dimana 1 petabytes $=1.000 .000$ gigabytes (Tarigan, 2003). Sedangkan MySQL dapat menyimpan data hingga 2 terabytes, dimana 1 terabytes = 1.000.000 gigabytes (Sun Microsystem, 2008).
Dalam hal kecepatan pemrosesan, Oracle memiliki tingkat kecepatan yang lebih baik dibandingkan dengan DBMS MySQL. Hasil penelitian sebelumnya menunjukkan bahwa sistem yang menggunakan DBMS Oracle mampu memproses 11 kali lebih cepat dibandingkan menggunakan DBMS MySQL (Nasution, 2008). Hal ini tentu akan sangat membantu dan menjadi persiapan jangka panjang mengingat data-data mahasiswa akan semakin besar dari waktu ke waktu sehingga membutuhkan sistem yang tangguh dalam kapasitas penyimpanan data maupun kecepatan pemrosesan.

RFID

(Radio-Frequency Identification) adalah sebuah metode identifikasi dengan menggunakan yang disebut label RFID atau transponder (tag) untuk menyimpan dan mengambil data jarak jauh. Teknologi ini mampu mengidentidfikasi berbagai objek secara simultan tanpa diperlukan kontak langsung atau dalam jarak pendek (Finkenzeller, 2003) dan juga teknologi ini juga digunakan dalam melakukan pengelolaan inventori dengan menggunakan smartphone berbasis android (Hamzah dan Purwati, 2017).

\section{METODE PENEITIAN}

RFID terdiri atas 2 komponen:

RFID Tag , dapat berupa stiker, kertas atau plastic dengan beragam ukuran. Dalam setiap tag terdapat chip yang mampu menyimpan sejumlah informasi tertentu. Sebuah tag yang dipasang tidak menggunakan sumber energi seperti batere sehingga dapat digunakan dalam waktu yang sangat lama.

RFID Terminal Reader, Terdiri atas RFID reader dan antenna yang akan mempengaruhi jarak optimal identifikasi. Reader mengirim gelombang elektromagnet, yang kemudian diterima oleh antena pada 
label RFID. Label RFID mengirim data biasanya berupa nomor serial yang tersimpan dalam label, dengan mengirim kembali gelombang radio ke reader.

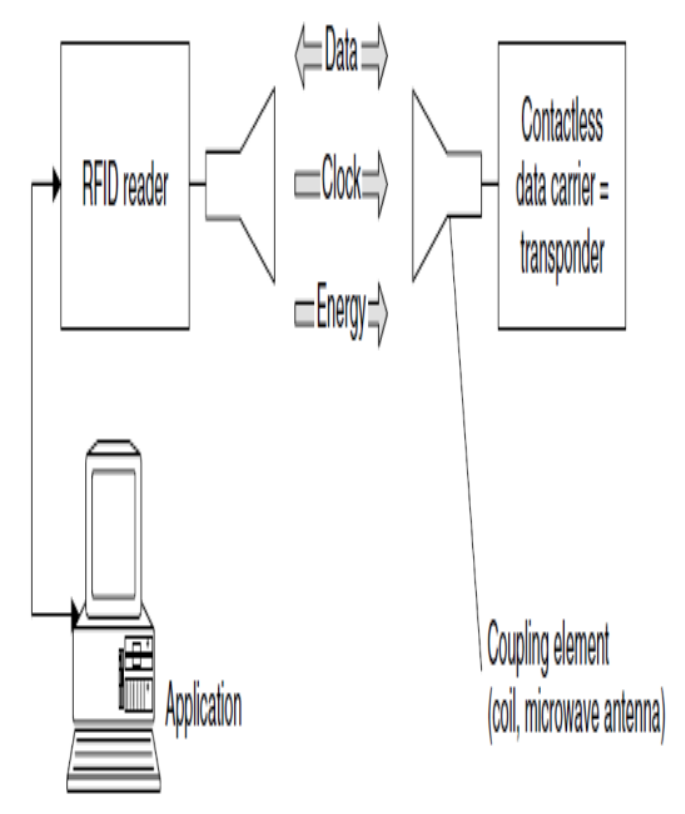

Sumber: (Finkenzeller, 2003).

Gambar 1. Ilustrasi proses komunikasi sistem RFID

\section{HASIL DAN PEMBAHASAN}

\section{Analisis}

Metode analisis yang digunakan penelitian ini dengan menggunakan metode analisis terstruktur dengan menggunakan teknik menentukan fakta, yaitu teknik mengumpulkan data (observasi) di Universitas Riau dan menentukan fakta-fakta dalam mempelajari kondisi yang ada di lapangan serta dalam perancangan sistem menggunakan metode beraliran data dengan menggunakan DFD (Data Flow Diagram) sebagai alat bantunya.

Dari hasi analisis didapati bahwa kondisi pencatatan kehadiran (presensi) mahasiswa adalah sebagai berikut: a. Pengisian presensi dilakukan secara manual dengan membubuhkan tanda tangan pada lembar presensi yang telah disediakan.

b. Jumlah presensi yang wajib diisi oleh mahasiswa adalah sebanyak 16 kali.

c. Form presensi disediakan untuk setiap kelas secara bertahap sebanyak 4 pertemuan per-lembar. Namun, ada juga beberapa Fakultas yang langsung menyediakan form untuk 16 pertemuan dalam satu lembar presensi.

d. Rekapitulasi presensi mahasiswa direkap setiap pertemuan ataupun secara berkala oleh petugas administrasi secara manual. Petugas administrasi melaporkan kepada Ketua Jurusan tentang perkembangan rekapitulasi presensi secara berkala.

e. Presentasi kehadiran mahasiswa menjadi salah satu komponen penilaian pada matakuliah tersebut. Jika mahasiswa tidak memenuhi minimal $80 \%$ kehadiran, maka mahasiswa tersebut tidak dibenarkan untuk mengikuti Ujian Akhir Semester.

f. Persentasi presensi menjadi syarat untuk mengikuti Ujian Akhir Semester (UAS). Presentasi dan rekapitulasi presensi kebanyakan baru diketahui oleh mahasiswa pada masa akhir semester dimana banyak terjadi kasus bahwa mahasiswa tidak bisa ikut UAS karena ternyata presentasi kehadiran tidak mencukupi minimal $80 \%$.

Dari hasil analisis yang dilakukan berdasarkan fakta yang ada, dapat diperoleh bahwa user yang akan menggunakan sistem terdiri atas 
admin sistem, dosen dan petugas administrasi.

\section{Perancangan}

Metode perancangan yang dikembangkan untuk membangun Sistem Presensi Online ini adalah dengan menggunakan metode perancangan beraliran data dengan menggunakan Data Flow Diagram (DFD).

Terdapat 3 user yang dapat berinteraksi dengan sistem, yakni :

a. Admin

User admin adalah pengguna sistem yang memiliki hak akses untuk memanajemen data dalam sistem, diantaranya data mahasiswa, data dosen, data matakuliah, data presensi, dan lain-lain.

b. Dosen

User dosen adalah pengguna sistem yang memiliki hak akses untuk melihat data mahasiswa, data presensi, data matakuliah dan dapat melakukan presensi terhadap mahasiswa pada tiap-tiap kelas yang diampu dengan menggunakan RFID scanner.

c. Petugas Administrasi

User Petugas administrasi adalah pengguna sistem yang memanajemen rekapitulasi presensi mahasiswa, memanajemen data administrasi perkuliahan sesuai dengan matakuliah dan dosen pengampu.

Sistem Presensi Online ini dirancang berbasis client server. Di setiap kelas akan terdapat komputer client yang menerima input data dari RFID reader dan diteruskan secara realtime ke komputer server. Setiap komputer client di tiap kelas terkoneksi melalui jaringan intranet ke komputer server. Setiap mahasiswa wajib membawa Kartu Tanda Mahasiswa pada setiap perkuliahan untuk melakukan presensi. Apabila mahasiswa tidak membawa KTM, maka presensi dapat dilakukan oleh Dosen melalui sistem.

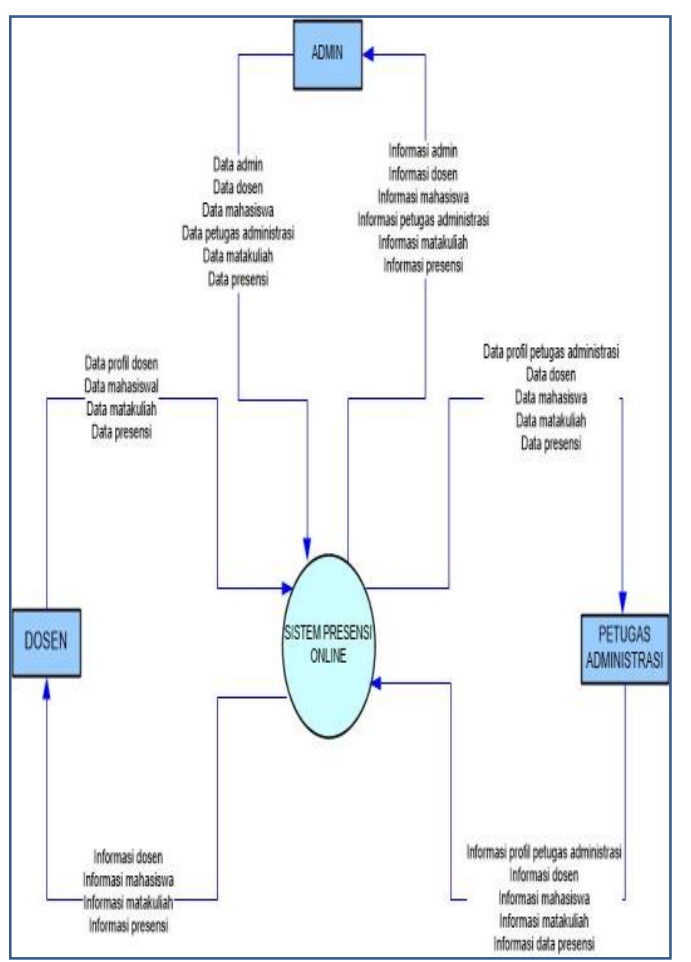

Gambar 2. DFD Level 0 (Context Diagram)

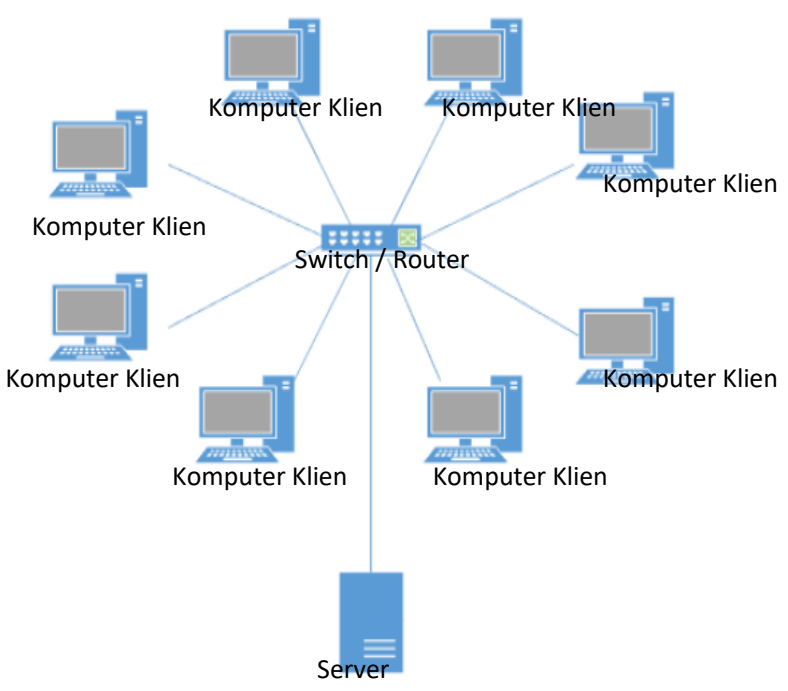

Gambar 3. Rancangan Arsitektur Sistem Presensi Online 
Cara kerja Sistem Presensi Online ini adalah sebagai berikut:

a. Sistem ini berbasis client server, dimana yang menjadi client adalah komputer reader RFID yang ada di setiap kelas, sedangkan yang menjadi server adalah komputer yang khusus menyimpan data presensi perkuliahan dari setiap komputer reader RFID.

b. Data absensi kuliah akan secara realtime terkirim dari komputer client ke komputer server sebagai pusat data.

c. Data mahasiswa pada Sistem Presensi Online disinkronkan dengan data yang ada pada Sistem Informasi Akademik, sehingga data mahasiswa tidak perlu dimasukkan ulang secara manual ke Sistem Presensi Online ini.

d. Mahasiswa melakukan tapping pada RFID reader yang terdapat di dalam kelas setiap akan memulai perkuliahan.

e. Proses aktivasi kelas dilakukan terlebih dahulu oleh dosen atau petugas administrasi, mahasiswa baru bisa melakukan presensi setelah kelas tersebut diaktivasi. Sehingga meminimalisir kecurangan terhadap proses presensi.

f. Rekapitulasi presensi otomatis tersimpan dan dapat dilihat kapan saja oleh mahasiswa saat melakukan tapping dan dapat dilihat oleh dosen dan petugas administrasi melalui fasilitas yang tersedia pada sistem.
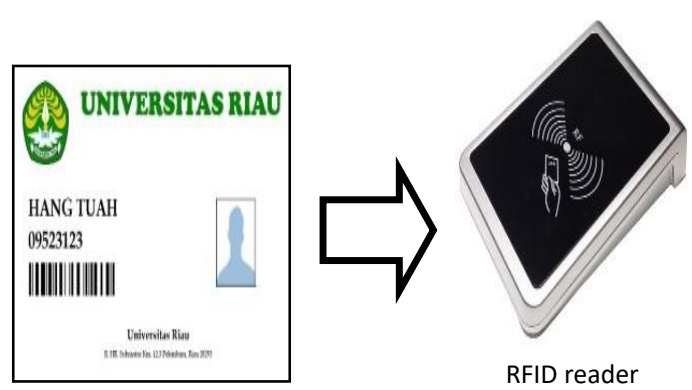

Kartu Mahasiswa

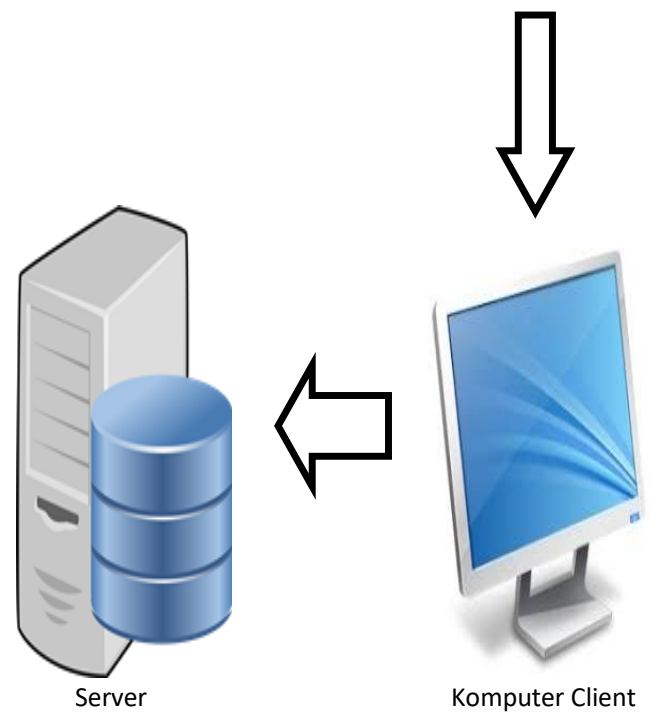
Gambar 4. Cara Kerja Sistem Presensi
Online

\section{SIMPULAN}

Proses pengisian presensi yang ada di Universitas Riau dilakukan secara manual dengan membubuhkan tanda tangan pada lembar presensi, data presensi tersebut direkap secara manual oleh petugas administrasi. Proses manual ini membutuhkan banyak waktu cukup lama untuk memperoleh rekapitulasinya.

Sistem Presensi Online dapat membantu pengelolaan data administrasi perkuliahan di Universitas Riau serta dapat mengurangi penggunaan kertas (paperless) karena menggunakan sistem yang terkomputerisasi. Sistem ini dapat memberikan kemudahan dalam melakukan presensi bagi mahasiswa 
karena presensi yang dilakukan dapat langsung diproses dan tersimpan di dalam sistem.

Sistem Presensi Online memberikan kemudahan kepada pengguna untuk memperoleh informasi terkait rekapitulasi presensi perkuliahan. Sistem ini juga dapat menjadi gudang arsip yang terkomputerisasi sehingga memberikan kemudahan dan kecepatan akses dalam memperoleh data yang diinginkan terkait presensi serta administrasi perkuliahan. 


\section{DAFTAR PUSTAKA}

Computing Channel. (2010). www.computingchannel.co.id.

Diakses pada 3 September 2010 dari

http://www.computingchannel.co. $\mathrm{id} /$ software/database/oraclesoftware-basis-data-yang-handal

Finkenzeller, K. (2003). RFID

Handbook : Fundamentals and Applications in Contactless Smart Cards and Identification, 2nd Edition. London: John Wiley \& Sons Finken

Hamzah, M. L., \& Purwati, A. A. (2017). Sistem Manajemen Inventori Komputer Menggunakan Near Field Communication Berbasis Android (Studi Kasus di STIE Pelita Indonesia Pekanbaru). Journal of Business and Accounting (COSTING), 1(1), 95-104

Oracle Corporation. (2018). MySQL 5.7 Reference Manual. www.oracle.com. Diakses pada 11 Januari 2018 pukul 10.00 dari https://dev.mysql.com/doc/refman /5.7/en/table-size-limit.html

Oracle Technology. (2017). www.oracle.com. Diakses pada 20 Desember 2017 pukul 14.00 dari

https://docs.oracle.com/database/1 21/CNCPT/intro.htm

Nasution, S. (2008). Sistem Manajemen Adminstrasi dan Presensi Online Laboratium Terpadu Informatika Menggunakan Oracle 10G dan Zend Core. www.rac.uii.ac.id. Diakses pada 7 Januari 2018 dari http://rac.uii.ac.id/harvester/index. $\mathrm{php} / \mathrm{record} / \mathrm{view} / 400060$

Tarigan, E. P. (2003). Menguasai Oracle $S Q L$. Jakarta
Want, R. (2006). An Introduction to RFID Technology. IEEE Pervasive Computing, 5(1), 25-33

Zend Technologies Ltd. (2015). www.zend.com. Diakses pada 8 Januari 2018 pukul 10.00 dari www.zend.com/en/community/ph $\mathrm{p}$ 